Hydrology and Earth System Sciences, 5(1), 119-131 (2001) (C) EGS

\title{
The potential for phosphorus pollution remediation by calcite precipitation in UK freshwaters
}

\author{
Colin Neal \\ Centre for Ecology and Hydrology (Wallingford), Wallingford, OXON, 10 BB, UK. \\ Email : cn@ceh.ac.uk
}

\section{Abstract}

This paper examines the potential for calcium carbonate to reduce phosphate pollution in freshwaters by co-precipitation, a process known as a "self cleansing mechanism". Calcium carbonate saturation levels and phosphate concentrations (SRP - soluble reactive phosphate) across the major eastern UK river basins are examined to test for solubility controls. The study shows that calcite saturation varies for each catchment as a function of flow and biological activity rather than by direct regulation by SRP. Indeed, there is no evidence, for any of the rivers studied, that calcite solubility controls hold. However, for groundwater and groundwater-fed springs in the Chalk of the Thames basin, calcite saturation is observed with associated low SRP levels. A self-cleansing mechanism may well be operative within the Chalk due to two factors. Firstly, there is a high potential for nucleation on the calcite micro-crystals in the aquifer. Secondly, there are within aquifer reactions that remove the calcite nucleating inhibitors (SRP and dissolved organic carbon, DOC) to levels lower than those occurring within the rivers do. These inhibitors enter the catchment at very high concentrations in association with agricultural pollution (fertilizer application and animal slurry) and household contamination (e.g. sewage sources from septic tanks). Under low flow conditions, when the saturation index for calcite is at its highest, so too is the concentration of the nucleation inhibitor SRP. Companion work shows that calcite precipitation can occur at the water-sediment interface of the river and this may involve SRP removal. The data, as a whole, define an apparent bound for calcite solubility control where in the presence of nucleating centres, SRP must be less than $4 \mathrm{mM}-\mathrm{P} \mathrm{l}^{-1}$ and DOC must be less than $150 \mathrm{mM}-\mathrm{C} 1^{-1}$ : a condition that does not seem to pertain within most UK rivers.

Keywords: calcite, calcium carbonate, phosphate, soluble reactive phosphate, dissolved organic carbon, LOIS, UK, rivers, self-cleansing mechanisms.

\section{Introduction}

High phosphate loadings associated with agriculture, industry and urbanization can result in excessive growth of aquatic plants, which, in turn, can lead to a decline in water quality associated with toxic algal blooms and reductions in dissolved oxygen levels. Furthermore, the water quality issue may be exacerbated due to changing patterns of climate variability as more severe low-flow extremes minimise pollutant dilution. Thus, phosphate pollution within the aquatic environment is of national and international importance in relation to ecological status and amenity value of rivers, estuaries, the coastal shelf and the open seas (Perry and Vanderklein, 1996; Crossland et al., 1999; Smith, 1999).

Knowledge of the key processes by which phosphorus is regulated within aquatic environments is an essential prerequisite for the development of computer based models needed to assess the impacts of phosphate pollution in relation to climate, agricultural, industrial and urbanization change. Such models are of strategic importance in formulating environmental management policies at national and international levels. The fate of phosphate in the aquatic environment is determined by a complex set of interactive hydrobiogeochemical processes (cf. Liss, 1976; Stumm and Morgan, 1997). Consequently, an integrated understanding of the hydrobiogeological functioning of phosphorus in river systems is missing.

In this paper, the importance of one particular process is examined. This process links calcium carbonate controls within river systems examined to issues of phosphate enrichment and the co-linkage between calcium carbonate precipitation and phosphate co-precipitation (House and Denison, 1997; Neal et al., 2001). At high calcium and bicarbonate concentrations and when photosynthesis becomes particularly active, calcium carbonate can precipitate if the kinetics of dissolution/precipitation of calcium carbonate is suitable. For calcium carbonate precipitation and phosphate co-precipitation to occur, four conditions must be met 
- The waters must be oversaturated with respect to calcium carbonate.

- The rate-limiting step of calcite precipitation must be overcome (Appelo and Postma, 1993).

- The phosphate concentration must be sufficiently low for it not to inhibit calcium carbonate precipitation (Walter and Hanor, 1979; Mucci, 1986; House, 1986, 1990).

- Other calcium carbonate precipitation inhibitors such as DOC (Berner et al., 1978; Suarez and Rhoades, 1982; Thomson, 1983; Inskeep and Bloom, 1986; Appelo and Postma, 1993) are below the levels where they affect the kinetics of precipitation.

With the reduction of pollutant source inputs due to tighter controls on fertilizer use and from sewage and industrial sources (including the promotion of upgraded sewage treatment to remove SRP from effluent discharges), phosphate levels within rivers have decreased generally (Mainstone et al., 2000). This, in turn, may allow the threshold between phosphate inhibition of calcium carbonate nucleation and phosphate co-precipitation with calcium carbonate to be crossed (Rossnecht, 1980; Kleiner, 1988; Hartley et al., 1996; House, 1986, 1990; House and Denison, 1997). Thus, for areas where phosphorus remediation is in progress, phosphorus reductions may lead to both direct discharge reductions and to a positive "self cleansing" feedback loop (Hartley et al., 1997; Neal et al., 2001). Correspondingly, for situations where phosphate pollutant levels increase, there may be an opposite pattern where selfcleansing mechanisms cease to operate.

In this paper, the degree of calcium carbonate saturation is examined for UK rivers across a range of environmental types, to see when/where there are co-linkages between calcium carbonate nucleation/inhibition and phosphate and dissolved organic carbon concentrations. The work brings together new information on calcium carbonate saturation levels at a broad scale and provides an overview of what type of river system can lead to self-cleansing mechanisms. For the study, the extensive data collected within the Land Ocean Interaction Study (LOIS: Leeks and Jarvie, 1998; Neal and Robson, 2000; Neal, 2001) and associated research (Langan et al., 1997; Cresser et al., 2000; Neal et al., 2000ae; Neal, 2001; Wade et al., 2001) are examined. The LOIS represents a major initiative to examine the water quality functioning of the major UK rivers draining into the North Sea and the rivers monitored covered a spectrum of catchment types from the River Tweed crossing the borders between England and Scotland in the North to the Humber Rivers in the Northeast and Midlands of England. The associated LOIS work provides information on three other major eastern English river basins draining into the North Sea (Wear, Great Ouse and the Thames) to extend the coverage to the southeast of England. In addition, the results of a community-based programme on Large Scale Processes in Ecology and Hydrology for the Dee in Scotland are included.

The work provides a broad basin-wide, regional and national perspective to set against more detailed process studies in this area of research (House and Denison, 1997; Jarvie et al., 2001; Neal et al., 2001). It is meant to encourage companion studies to examine in more detail the potential for SRP attenuation by calcium carbonate solubility controls

- at sediment/plant interfaces with the water column

- within the estuarine and coastal environments under programmes such as the Land Ocean Interactions in the Coastal Zone (LOICZ: Crossland et al., 1999).

\section{Study area}

The study area encompasses the main river basins from the Dee in north-eastern Scotland to the Thames in southern England. Six main areas are represented in this study. The salient features of these areas are described below with reference sources for further detail.

The River Dee The Dee basin is a large UK basin $\left(2100 \mathrm{~km}^{2}\right)$ of an acid-moorland/rural type. It is divided broadly into uplands in the western half and lowlands in the eastern half of the basin (Langan et al., 1997; Cresser et al., 2000). The western area is dominated by the Cairngorm Mountains with acidic moorland soils and bogs. However, there are some areas of the uplands where there are calcium rich rocks and these produce less acidic soils. In the eastern lowland areas, the topography is less steep and the land is used mainly for arable production and grazing. For the lowland areas, most of the soils are ploughed deeply and lime applications enhance soil nutrition and counteract the soil acidity. The water quality of the region varies markedly (Smart et al., 1998). In the uplands, the waters are acidic particularly under highflow conditions in the areas where acidic soils dominate. For the lowland areas, the waters are less acidic and the changes in water quality are relatively small owing to the restricted differences in the groundwater and soil water chemistries. Reference is made to a basin-wide monitoring study of Smart et al. (1998) across sixty sites covering the main upland and lowland catchments as well as several sites along the main stem of the Dee. The water quality of the region varies from acidic types (with acid sensitive/ vulnerable ecology) in the uplands (under highflow conditions) good quality to poorer quality and eutrophic 
waters in the lowlands (Langan et al., 1997; Smart et al., 1998; Wade et al., 2001).

The Tweed This represents a rural river system, a site of special scientific interest, located in the eastern border between Scotland and England. The catchment is large (about $4400 \mathrm{~km}^{2}$ ) with low-intensity agriculture ranging from upland areas of moorland and rough pasture for hill sheep farming to arable tilled regions in the lowlands. The geology of the basin comprises mainly sedimentary and metamorphosed sedimentary rocks (Ordovician and Silurian age greywacke, shale and mudstone, Old Red Sandstone and Carboniferous age shale, greywacke and limestone). Further, Old Red Sandstone Age igneous rocks (intrusive granites and extrusive basic lavas) occur to the south of the area in the Cheviot Hills. Three sites have been monitored. The catchment may be categorised "as rural" and the water is of good quality (Neal et al., 1997; Robson and Neal, 1997).

The Wear This is one of the main rivers in the north-east of England. Its basin has an area of about $1044 \mathrm{~km}^{2}$. It provides an example of a system influenced by derelict lead-zinc and coal mining activity with associated mine-water pumping. The underlying geology is Carboniferous age Limestone, Millstone Grit, Coal Measure shales and mudstones and the upper half of the catchment has extensive heavy metal vein mineralisation (North Pennine lead-zinc orefield). Moorlands dominate the landscape and there has been extensive historic lead-zinc mining activity with numerous spoil heaps particularly in the upper parts of the catchment. The landscape of the lower reaches of the Wear is dominated by arable farmland. The catchment has a long history of coal mining, sand/aggregate and shale extraction close to the river, leading to problems with the discharge of mine-water. The water quality is fair to good except where sewage and mine drainage sources reduce its quality (Neal et al., 2000a).

The Humber Rivers The Humber Rivers drain into the North Sea at the Humber estuary in northern England (Jarvie et al., 1997). The bedrock varies from sedimentary rocks of Carboniferous and New Red Sandstone age (primarily sandstone, grit and limestone) in the upland areas to the west of the region and to Jurassic and Cretaceous age sandstone and limestone to the lowland east of the region. The northern Humber Rivers (Swale, Ure, Nidd, Ouse, Derwent and Wharf) drain essentially moorland areas near their sources to agricultural land in the lowland areas. In general, the water quality of these rivers is good to fair although there is some deterioration due to metal release from contaminated flood plain materials derived from historic mining activity and sewage inputs of nutrients from the conurbations (Neal et al., 2000f). The southern Humber Rivers (Aire, Calder, Don and Trent) drain from moorland source areas through the industrial heartland of north-eastern and central England. For the urban/industrial rivers, the water quality is poor in consequence to point sources of pollutants of nutrients, micro-organics and metals (Neal et al., 2000f).

The Great Ouse The Great Ouse provides the main river basin of the southern part of the English midlands and East Anglia. It drains through Upper Jurassic clays and Cretaceous Chalk into the Wash. In the process, it flows through several market towns and major lowland areas of intensive agriculture. The Great Ouse basin covers an area of $8600 \mathrm{~km}^{2}$ and has a population of 1.6 million. One sampling site has been monitored, at Great Paxton; the catchment area to this point is about $2500 \mathrm{~km}^{2}$. The water chemistry at this point is of a calcium bicarbonate type that is enriched in nutrients and is of moderate to good quality (Neal et al., 2000b).

The Thames The Thames is the major river draining southern-central and southeast England. The data presented here relate to water quality monitoring at a site on the mainstem of the river and on two tributaries further downstream (the Pang and the Kennet). The upper Thames, monitored about half way along its length, mid-way between the towns of Oxford and Reading, covers a large rural mixed-farming area of about $3500 \mathrm{~km}^{2}$ (Neal et al., 2000c). The bedrock comprises mixed sedimentary geology of Oolitic limestone in the headwater areas and Oxford clays and minor Cretaceous age sedimentary rocks in the lower parts of the catchment. For the tributary sites, the geology and land use is similar to the main Thames. In the case of the Pang, four sites have been monitored (Neal et al., 2000d) while for the Kennet, six streams and three boreholes have been monitored (Neal et al., 2000e): the catchment areas are about $171 \mathrm{~km}^{2}$ and about $1200 \mathrm{~km}^{2}$, respectively. The water quality of the Thames area including the tributary sites described in this paper is moderate to good, being influenced by calcium bicarbonate bearing groundwater sources, agricultural inputs of nutrients and micro-organics and sewage inputs of nutrients.

\section{C alcium carbonate saturation assessment}

For calcium carbonate equilibrium in water,

- The activity product for calcium and carbonate ions $\left(\left\{\mathrm{Ca}^{2+}\right\} *\left\{\mathrm{CO}_{3}^{2-}\right\}\right)$ is constant at any given temperature.

- This activity product equals a thermodynamic equilibrium constant, $\mathrm{K}_{\mathrm{CaCO} 3}$, for one of the several different forms of calcium carbonate that occur in nature 
(e.g. calcite and aragonite).

- All the forms of calcium carbonate have a similar value for $\mathrm{K}_{\mathrm{CaCO} 3}$.

The degree of calcite saturation, the saturation index $\left(\mathrm{SI}_{\text {Calcite }}\right)$ is defined in logarithmic form as:

$$
\log \left(\mathrm{SI}_{\text {Calcite }}\right)=\log _{10}\left(\left\{\mathrm{Ca}^{2+}\right\} *\left\{\mathrm{CO}_{3}^{2-}\right\}\right)-\log _{10}\left(\mathrm{~K}_{\mathrm{CaCO} 3}\right)
$$

For the saturation expression, a $\log \left(\mathrm{SI}_{\text {Calcite }}\right)$ value of zero corresponds to calcite saturation, while values of +1 and -1 correspond to ten times and one-tenth saturation respectively. For the present study, the saturation index is determined by the modified method of Neal et al. (1998) with allowances being made for the important complexes that make up the calcium and alkalinity values $\left(\mathrm{H}_{2} \mathrm{CO}_{3}, \mathrm{HCO}_{3}{ }^{-}, \mathrm{CO}_{3}{ }^{2-}\right.$, $\mathrm{CaHCO}_{3}^{+}, \mathrm{CaCO}_{3}{ }^{0}, \mathrm{CaOH}^{+}$).

The primary form of $\mathrm{CaCO}_{3}$ occurring within UK and many other rivers is calcite. For simplicity, within this study, only solubility with respect to this phase is considered and $\mathrm{K}_{\mathrm{CaCO} 3}=\mathrm{K}_{\text {Calcite }}$ under this situation.

\section{Results}

\section{GENERAL}

A summary of the water quality of the study areas is presented in Tables 1, 2 and 3 for the three measures of importance in this paper, $\operatorname{logSI_{\text {Calcite}}}$, SRP and DOC, respectively; the average, minimum and maximum values provide the basic statistics. However, low flow and high flow averages, presented to show the influence of hydrology, were obtained by taking the average chemistries for the five lowest and the five highest flows, respectively. Within the paper, extensive reference is given to the relationship between the logarithm of the saturation index and the $\mathrm{pH}$ for each river or groundwater system. To show the extent of this relationship, Table 4 contains a statistically based linear regression analysis for the individual sites.

The rivers and groundwaters show over a six order of magnitude range in calcite saturation: from about a hundredfold undersaturation to a hundred thousand-fold oversaturation. Correspondingly, there are large variations in the concentrations of SRP $\left(<1\right.$ to $\left.120 \mathrm{mM}-\mathrm{P}^{-1}\right)$ and DOC (10 to $\left.6000 \mathrm{mM}-\mathrm{Cl}^{-1}\right)$. However, the calcite saturation levels, $\mathrm{SRP}$, and DOC concentrations vary from river to river and these differ from the groundwaters monitored. The salient features are described for five typological groupings characterising the various hydrochemical regimes: acidic upland, rural, industrial/urban, agricultural and groundwaterfed. The salient features are described below.

The acidic uplands
These comprise the upland areas of the Dee system. For these sites, the concentration of SRP is low, mainly less than $2 \mathrm{mM}$ $\mathrm{P}^{-1}$ and, most often, less than $0.2 \mathrm{mM}-\mathrm{P}^{-1}$, and these areas are often phosphorus limited. Correspondingly, these areas have relatively high concentration of DOC (mean 350, range $12-2586 \mathrm{mM}-\mathrm{C}^{-1}$ ). The waters are undersaturated with respect to calcite by two to five orders of magnitude $\left(\operatorname{logSI} \mathrm{Calcit}_{\text {in }}\right.$ range for the sum of all the sites is -5.1 to 0.2$)$. In essence, for these systems, the water chemistry is highly flowdependent (Wade et al., 2001). Under stormflow conditions, the waters are derived mainly from the acidic soil zones and hence the waters are at their most acidic with $\mathrm{pH}$ as low as 4.2 and they are rich in organic carbon (over $2000 \mathrm{mM}-\mathrm{Cl}^{-1}$ ). In contrast, the baseflow waters are less acidic ( $\mathrm{pH}$ up to 8.0) as they drain the lower soil and bedrock zones where weathering of silicate phases is higher and hence the waters are less acidic and lower in DOC. At no point (other than for one outlier value) is the weathering sufficiently high to increase the calcium and bicarbonate concentrations to levels where the waters become oversaturated with respect to calcite. Rather, there is a systematic change with the highest degree of undersaturation occurring under stormflow conditions and the lowest degree of undersaturation occurring under baseflow conditions. Indeed, the saturation index for calcite varies linearly with the $\mathrm{pH}$ (gradient approximately 2) and this reflects (a) a co-variance as the logarithm of the calcite saturation index is computed using $\mathrm{pH}$ and (b) a systematic change in bicarbonate, calcium and $\mathrm{pH}$ which decrease with increasing flow (cf. Neal et al., 2000c and Wade et al., 2001).

Within the upland parts of the Dee basin, there are also small areas with basic rocks where slightly higher $\mathrm{pH}$ values are observed (a range of $\mathrm{pH}$ of 8.6 to 5.6). Here, the waters vary in calcite saturation between about saturation to over five orders of magnitude undersaturation. The value reaching saturation is an outlier point and is atypical. The linear pattern between calcite saturation is observed throughout the $\mathrm{pH}$ range with no levelling of slope around calcite saturation.

Thus, across the upland region it is clear that there is essentially no potential for calcite solubility controls within this system as (a) strong linear features are invariably found between $\log \left(\mathrm{SI}_{\text {Calcite }}\right)$ and $\mathrm{pH}$ and (b) almost all the waters analysed were greatly calcite undersaturated.

\section{The rural catchments}

These comprise the lowland part of the Dee system, the Tweed, the Yorkshire Ouse and its tributaries (the Swale, Ure and Nidd), the Wharf and the Derwent. For all these systems, calcite saturation varies between under- and oversaturation. The salient features are: 
Table 1. Logarithm of the calcite saturation index $\left(\operatorname{logSI_{\text {Calcite}}}\right)$ in selected UK rivers and groundwaters. For the Dee, a summary is given for the three types of catchment (upland acidic, upland basic and lowland) following the work of Wade et al. 2001. The italicised terms refer to the groundwater samples for the Kennet area (Kennet B1, B2 and B3) and the spring on the Pang (Pang2).

\begin{tabular}{|c|c|c|c|c|c|}
\hline & $\begin{array}{l}\log S I_{\text {Calcite }} \\
\text { Average }\end{array}$ & $\begin{array}{l}\log S I_{\text {Calcite }} \\
\text { Minimum }\end{array}$ & $\begin{array}{l}\log S I_{\text {Calite }} \\
\text { Maximum }\end{array}$ & $\begin{array}{l}\log S I_{\text {Calcite }} \\
\text { Low flow }\end{array}$ & $\begin{array}{l}\log S I_{\text {Calcite }} \\
\text { High flow }\end{array}$ \\
\hline Dee up-acidic & -3.5 & -5.1 & 0.2 & -2.3 & -5.1 \\
\hline Dee up-basic & -1.9 & -5.6 & 0.1 & -0.9 & -3.2 \\
\hline Dee lowland & -1.6 & -4.0 & 1.1 & -1.3 & -2.1 \\
\hline Tweed1 & 0.3 & -1.7 & 1.7 & 0.8 & -0.1 \\
\hline Tweed2 & -0.0 & -2.1 & 1.2 & 0.1 & -0.5 \\
\hline Tweed3 & 0.1 & -2.3 & 1.9 & 1.4 & -0.8 \\
\hline Wear & -0.2 & -1.0 & 0.4 & 0.2 & -0.6 \\
\hline Swale1 & 0.1 & -1.7 & 1.4 & 1.0 & -0.8 \\
\hline Swale2 & 0.3 & -1.4 & 1.5 & 1.0 & -0.6 \\
\hline Ure & 0.2 & -1.8 & 1.4 & 1.0 & -0.7 \\
\hline Nidd & -0.3 & -1.7 & 1.1 & -0.2 & -0.7 \\
\hline Ouse1 & 0.2 & -1.3 & 1.6 & 0.8 & -0.2 \\
\hline Ouse 2 & 0.1 & -1.5 & 1.5 & 0.6 & -0.5 \\
\hline Derwent & 0.4 & -0.8 & 1.2 & 0.7 & 0.1 \\
\hline Wharf & 0.2 & -1.3 & 1.6 & 0.6 & -0.4 \\
\hline Aire & -0.2 & -1.3 & 0.9 & 0.3 & -0.7 \\
\hline Calder & -0.5 & -1.9 & 1.0 & -0.2 & -1.1 \\
\hline Don & -0.1 & -1.3 & 0.8 & 0.2 & -0.6 \\
\hline Trent & 0.7 & -0.6 & 1.7 & 0.8 & 0.1 \\
\hline Gt Ouse & 0.8 & 0.4 & 1.6 & 0.7 & 0.8 \\
\hline Thames & 1.1 & 0.6 & 2.2 & 1.2 & 0.7 \\
\hline Kennet1 & 0.6 & 0.2 & 1.3 & 1.0 & 0.7 \\
\hline Kennet2 & 0.6 & 0.3 & 1.3 & 0.5 & 0.6 \\
\hline Kennet3 & 0.6 & 0.2 & 1.1 & 0.5 & 0.7 \\
\hline Kennet4 & 0.7 & 0.3 & 1.2 & 0.7 & 0.7 \\
\hline Kennet5 & 0.8 & 0.4 & 1.2 & 0.8 & 0.8 \\
\hline Kennet6 & 0.9 & 0.4 & 1.6 & 1.0 & 0.8 \\
\hline Kennet7 & 0.8 & 0.4 & 1.2 & 0.8 & 0.8 \\
\hline Kennet B1 & -0.1 & -0.1 & -0.0 & $N A$ & $N A$ \\
\hline Kennet B2 & -0.1 & -0.1 & -0.0 & $N A$ & $N A$ \\
\hline Kennet B3 & -0.1 & -0.1 & 0.0 & $N A$ & $N A$ \\
\hline Pang1 & 0.6 & 0.2 & 0.9 & 0.6 & 0.6 \\
\hline Pang2 & 0.1 & 0.0 & 0.3 & NA & NA \\
\hline Pang3 & 0.8 & 0.5 & 1.0 & 0.8 & 0.8 \\
\hline Pang4 & 0.8 & 0.2 & 1.2 & 0.8 & 0.6 \\
\hline
\end{tabular}

- For the Tweed, the Yorkshire Ouse and its tributaries, the Derwent and the Wharf, under baseflow conditions the waters are typically calcite oversaturated by a factor of two to ten. Under highflow conditions, they are calcite oversaturated by a factor typically up to an order of magnitude.
- For the lowland Dee, a similar pattern to the other sites occurs with respect to flow. However, the more acidic nature of the Dee ensures that there is a higher degree of calcite undersaturation under high flow conditions (typically about a hundred-fold undersaturated). The degree of saturation varies from site-to-site across the 
Table 2. Soluble reactive phosphorus in selected UK rivers and groundwaters: units $\mu \mathrm{M}-\mathrm{P}^{-1}$. For the Dee, a summary is given for the three types of catchment (upland acidic, upland basic and lowland) following the work of Wade et al. 2001. For the Dee, totaldissolved rather than soluble reactive phosphorus was measured: it would be expected that these two terms would be similar. The italicised terms refer to the groundwater samples for the Kennet area (Kennet B1, B2 and B3) and the spring on the Pang (Pang2).

\begin{tabular}{|c|c|c|c|c|c|}
\hline & $\begin{array}{l}\text { SRP } \\
\text { Average }\end{array}$ & $\begin{array}{l}\text { SRP } \\
\text { Minimum }\end{array}$ & $\begin{array}{l}\text { SRP } \\
\text { Maximum }\end{array}$ & $\begin{array}{l}S R P \\
\text { Low flow }\end{array}$ & $\begin{array}{l}\text { SRP } \\
\text { Highflow }\end{array}$ \\
\hline Dee up-acidic & 0.1 & 0.0 & 1.5 & - & - \\
\hline Dee up-basic & 0.3 & 0.0 & 37.7 & - & - \\
\hline Dee lowland & 0.9 & 0.0 & 4.4 & - & - \\
\hline Tweed1 & 1.4 & 0.0 & 16.1 & 1.0 & 1.3 \\
\hline Tweed2 & 1.2 & 0.0 & 8.8 & 2.0 & 0.9 \\
\hline Tweed3 & 1.0 & 0.0 & 2.7 & 0.5 & 1.3 \\
\hline Wear & 10.5 & 1.4 & 30.5 & 22.0 & 3.5 \\
\hline Swale1 & 3.4 & 0.5 & 20.7 & 5.3 & 1.0 \\
\hline Swale2 & 6.0 & 0.9 & 18.7 & 11.4 & 2.3 \\
\hline Ure & 1.8 & 0.1 & 5.5 & 4.1 & 1.3 \\
\hline Nidd & 16.9 & 1.2 & 54.5 & 37.9 & 4.6 \\
\hline Ouse1 & 6.5 & 0.0 & 30.2 & 16.1 & 2.8 \\
\hline Ouse 2 & 11.6 & 0.2 & 37.1 & 31.8 & 2.0 \\
\hline Derwent & 4.0 & 0.7 & 11.9 & 7.0 & 0.7 \\
\hline Wharf & 5.6 & 0.5 & 15.0 & 10.3 & 1.7 \\
\hline Aire & 31.0 & 0.8 & 83.3 & 57.5 & 12.0 \\
\hline Calder & 32.9 & 1.2 & 87.1 & 46.4 & 7.7 \\
\hline Don & 44.4 & 1.2 & 113.2 & 32.5 & 6.5 \\
\hline Trent & 51.4 & 9.8 & 104.0 & 80.8 & 12.7 \\
\hline Gt Ouse & 51.2 & 7.2 & 102.2 & 75.2 & 13.7 \\
\hline Thames & 28.7 & 5.1 & 67.8 & 52.3 & 7.3 \\
\hline Kennet1 & 2.3 & 0.0 & 14.3 & 1.2 & 5.3 \\
\hline Kennet2 & 5.3 & 1.3 & 20.7 & 6.0 & 3.1 \\
\hline Kennet3 & 5.5 & 1.2 & 22.3 & 6.3 & 4.2 \\
\hline Kennet4 & 4.9 & 1.2 & 19.4 & 6.1 & 4.5 \\
\hline Kennet5 & 5.1 & 1.0 & 21.6 & 5.9 & 4.4 \\
\hline Kennet6 & 4.2 & 0.4 & 16.3 & 4.8 & 3.9 \\
\hline Kennet7 & 3.3 & 0.5 & 11.3 & 3.3 & 1.2 \\
\hline Kennet B1 & 0.5 & 0.0 & 0.6 & $N A$ & $N A$ \\
\hline Kennet B2 & 0.6 & 0.0 & 0.7 & $N A$ & $N A$ \\
\hline Kennet B3 & 0.4 & 0.3 & 0.5 & $N A$ & $N A$ \\
\hline Pang1 & 2.5 & 0.4 & 7.0 & 3.4 & 2.0 \\
\hline Pang2 & 1.2 & 0.4 & 3.7 & $N A$ & $N A$ \\
\hline Pang3 & 1.8 & 0.2 & 6.2 & 2.0 & 1.8 \\
\hline Pang4 & 2.4 & 0.6 & 13.2 & 2.4 & 2.1 \\
\hline
\end{tabular}

Dee. For all but three sites, the waters are permanently undersaturated with respect to calcite. The values range from about ten times oversaturated (where photosynthesis elevates $\mathrm{pH}$ to over nine) to four orders of magnitude undersaturated.
- For all the rivers where calcite oversaturation occurs, the waters are of their greatest oversaturation at times of high photosynthetic activity. This is most marked for the Tweed, where particularly high photosynthetic activity coupled with moderate alkalinities leads to 
Table 3. Dissolved organic carbon in selected UK rivers and groundwaters: units $\mu \mathrm{M}-\mathrm{C}^{-1}$. For the Dee, a summary is given for the three types of catchment (upland acidic, upland basic and lowland) following the work of Wade et al., 2001. For the Dee, total oxidisable carbon has been measured rather than dissolved organic carbon. The italicised terms refer to the groundwater samples for the Kennet area (Kennet B1, B2 and B3) and the spring on the Pang (Pang2).

\begin{tabular}{|c|c|c|c|c|c|}
\hline & $\begin{array}{l}\text { DOC } \\
\text { Average }\end{array}$ & $\begin{array}{l}\text { DOC } \\
\text { Minimum }\end{array}$ & $\begin{array}{l}\text { DOC } \\
\text { Maximum }\end{array}$ & $\begin{array}{l}\text { DOC } \\
\text { Low flow }\end{array}$ & $\begin{array}{l}\text { DOC } \\
\text { Highflow }\end{array}$ \\
\hline Dee up-acidic & 350 & 12.0 & 2586.0 & 166.0 & 778.0 \\
\hline Dee up-basic & 329 & 35.0 & 2401.0 & 144.0 & 730.0 \\
\hline Dee lowland & 463 & 115.0 & 2057.0 & 308.0 & 765.0 \\
\hline Tweed1 & 335.7 & 148.3 & 1002.0 & 228.3 & 729.9 \\
\hline Tweed2 & 249.1 & 55.8 & 708.9 & 169.6 & 511.4 \\
\hline Tweed3 & 334.8 & 124.2 & 1150.8 & 233.1 & 563.9 \\
\hline Wear & 359.8 & 175.0 & 891.7 & 277.8 & 509.7 \\
\hline Swale1 & 392.9 & 146.7 & 1937.3 & 218.6 & 732.0 \\
\hline Swale2 & 418.1 & 146.7 & 1722.5 & 236.2 & 447.6 \\
\hline Ure & 390.9 & 122.5 & 1833.0 & 262.3 & 508.9 \\
\hline Nidd & 473.6 & 195.8 & 1014.7 & 401.5 & 635.6 \\
\hline Ouse1 & 438.1 & 188.3 & 1743.3 & 315.8 & 586.9 \\
\hline Ouse2 & 491.7 & 209.2 & 1305.9 & 444.4 & 438.5 \\
\hline Derwent & 346.1 & 122.5 & 5318.3 & 270.6 & 542.2 \\
\hline Wharf & 426.3 & 160.0 & 6136.7 & 358.6 & 529.5 \\
\hline Aire & 816.2 & 185.0 & 1526.7 & 977.1 & 659.0 \\
\hline Calder & 928.1 & 254.2 & 2192.5 & 955.8 & 629.0 \\
\hline Don & 492.6 & 126.7 & 1106.7 & 679.4 & 486.5 \\
\hline Trent & 510.5 & 130.0 & 915.8 & 487.4 & 529.0 \\
\hline Gt Ouse & 475.9 & 333.3 & 766.7 & 500.0 & 591.7 \\
\hline Thames & 367.4 & 225.0 & 816.7 & 348.6 & 620.8 \\
\hline Kennet1 & 151.0 & 75.0 & 275.0 & 83.3 & 233.3 \\
\hline Kennet2 & 141.2 & 91.7 & 225.0 & 108.3 & 200.0 \\
\hline Kennet3 & 138.6 & 83.3 & 225.0 & 125.0 & 200.0 \\
\hline Kennet4 & 164.5 & 100.0 & 225.0 & 183.3 & 225.0 \\
\hline Kennet5 & 151.8 & 100.0 & 208.3 & 125.0 & 125.0 \\
\hline Kennet6 & 139.6 & 91.7 & 225.0 & 125.0 & 183.3 \\
\hline Kennet7 & 134.9 & 83.3 & 216.7 & 116.7 & 183.3 \\
\hline Kennet B1 & $N A$ & $N A$ & $N A$ & $N A$ & $N A$ \\
\hline Kennet B2 & $N A$ & $N A$ & $N A$ & $N A$ & $N A$ \\
\hline Kennet B3 & $N A$ & $N A$ & $N A$ & $N A$ & $N A$ \\
\hline Pang1 & 113.8 & 75.0 & 350.0 & 155.6 & 83.3 \\
\hline Pang2 & 97.1 & 66.7 & 141.7 & $N A$ & $N A$ \\
\hline Pang3 & 167.1 & 91.7 & 233.3 & 159.4 & 141.7 \\
\hline Pang4 & 209.8 & 75.0 & 575.0 & 209.8 & 513.9 \\
\hline
\end{tabular}

abnormally high $\mathrm{pHs}$ (greater than nine and up to 10.5).

- SRP concentrations are relatively low for the rural catchments compared to the systems dominated by agricultural and urban/industrial sources (mean values being typically less than $12 \mathrm{mM}-\mathrm{P} \mathrm{l}^{-1}$ with a range from less than the detection level to about $55 \mathrm{mM}-\mathrm{P}^{-1}$ ). The patterns of phosphorus behaviour vary. For the Dee, the Tweed and the Ure, SRP concentrations are particularly low (usually much less than $40 \mathrm{mM}-\mathrm{P}^{-1}$ ). However, there are higher values for the Nidd and the lower Ouse (site 
Table 4. Linear regression analysis of $\mathrm{pH}$ against the logarithm of the saturation index for selected UK river waters and groundwaters: $\operatorname{logS\mathrm {S}_{\text {Calcite}}}=\mathrm{m} * \mathrm{pH}+\mathrm{c}$ where $\mathrm{m}$ is the gradient and $\mathrm{c}$ is a constant. For the Dee, a summary is given for examples of the three types of catchment (upland acidic, upland basic and lowland) following the work of Wade et al. 2001. The italicised terms refer to the groundwater samples for the Kennet area (Kennet B1, B2 and B3) and the spring on the Pang (Pang2). For the Kennet, the data for the three boreholes sampled have been combined together for a single regression (denoted in the table as Kennet Bs) owing to the limited number of samples available for each site.

\begin{tabular}{lcclr}
\hline & Gradient & Constant & $r^{2}$ & \multicolumn{1}{r}{$N$} \\
\hline Dee up-acidic & 2.13 & -18.2 & 0.97 & 27 \\
Dee up-basic & 2.13 & -17.9 & 0.961 & 27 \\
Dee lowland & 1.63 & -13.4 & 0.945 & 27 \\
Tweed1 & 0.96 & -7.6 & 0.730 & 119 \\
Tweed2 & 0.91 & -8.0 & 0.822 & 119 \\
Tweed3 & 1.11 & -9.3 & 0.890 & 119 \\
Wear & 1.15 & -8.9 & 0.297 & 55 \\
Swale1 & 1.28 & -10.1 & 0.708 & 172 \\
Swale2 & 1.42 & -10.9 & 0.716 & 183 \\
Ure & 1.34 & -10.4 & 0.691 & 180 \\
Nidd & 1.01 & -8.1 & 0.744 & 184 \\
Ouse1 & 1.22 & -9.4 & 0.710 & 188 \\
Ouse2 & 1.20 & -9.2 & 0.701 & 153 \\
Derwent & 1.06 & -7.9 & 0.783 & 177 \\
Wharf & 1.16 & -8.9 & 0.747 & 192 \\
Aire & 1.01 & -7.7 & 0.643 & 207 \\
Calder & 1.03 & -8.1 & 0.460 & 186 \\
Don & 1.14 & -8.7 & 0.763 & 189 \\
Trent & 1.14 & -8.4 & 0.903 & 164 \\
Gt Ouse & 1.18 & -8.7 & 0.940 & 58 \\
Thames & 1.05 & -7.5 & 0.924 & 108 \\
Kennet1 & 0.92 & -6.4 & 0.914 & 154 \\
Kennet2 & 1.11 & -7.9 & 0.946 & 156 \\
Kennet3 & 1.05 & -7.5 & 0.943 & 159 \\
Kennet4 & 1.06 & -7.6 & 0.937 & 158 \\
Kennet5 & 1.00 & -7.1 & 0.914 & 158 \\
Kennet6 & 0.92 & -6.4 & 0.974 & 158 \\
Kennet7 & 1.02 & -7.3 & 0.915 & 158 \\
Kennet Bs & 0.35 & -2.5 & 0.256 & 28 \\
Pang1 & 1.05 & -7.5 & 0.914 & 20 \\
Pang2 & 1.06 & -7.5 & 0.846 & 20 \\
Pang3 & 1.23 & -8.9 & 0.923 & 20 \\
Pang4 & 1.35 & -9.9 & 0.879 & 104 \\
\hline & & & & \\
\hline
\end{tabular}

Ouse 2 in the tables) owing to point source inputs of sewage effluent and under baseflow conditions SRP levels may reach up to the maximum of $55 \mathrm{mM}-\mathrm{P} \mathrm{l}^{-1}$ : at these sites, the concentrations dilute with increasing flow.

- DOC averages from about 200 to about $400 \mathrm{mM}-\mathrm{C}^{-1}$ and ranges from about $50 \mathrm{mM}-\mathrm{C}^{-1}$ to a maximum typically of around $2000 \mathrm{mM}-\mathrm{C}^{-1}$ for the rural catchments. In the case of the Tweed and the Nidd, the highest concentrations are lower at around $1100 \mathrm{mM}-\mathrm{C}$ $\mathrm{I}^{-1}$ while for the Wharf and the Derwent, there are high outlier values (around $6000 \mathrm{mM}-\mathrm{Cl}^{-1}$ ). In general, DOC concentrations increase moderately with increasing flow.

- For all sites, there is a positive linear relationship between the logarithm of the calcite saturation and the $\mathrm{pH}$, of high statistical significance, with no "levelling off" near calcite saturation. Thus, the calcite saturation data do not indicate that a solubility control is operative across the rural systems. However, there is a potential for calcite precipitation under low-flow conditions across all but those of more acidic character.

\section{The industrial/urban catchments}

These rivers comprise the southern Humber basin, the Aire, Calder, Don and Trent as well as the Wear. They all show water quality characteristics similar to the more northerly rural rivers of the Humber (Swale, Ure, Nidd, Ouse, Wharf and Derwent) except that the SRP levels are higher except for the Wear. Considering first the industrial/urban rivers of the Humber and then the Wear separately, the salient points are as follows.

The urban/industrial rivers of the Humber.

For these, rivers, the salient features are:

- The SRP concentrations are relatively high with a mean of 30 to $52 \mathrm{mM}-\mathrm{P}^{-1}$ and a range of about 1 to $113 \mathrm{mM}$ $\mathrm{P}^{-1}$. Most of the SRP comes from point sources and hence concentrations dilute with increasing flow.

- DOC concentrations average around 500 to $900 \mathrm{mM}$ $\mathrm{Cl}^{-1}$ and range between 120 and $2200 \mathrm{mM}-\mathrm{Cl}^{-1}$. Concentrations generally decline to a small degree with increasing flow in line with the dilution of point sources. However, DOC concentration variation with flow is complex as there is also a highflow DOC component associated with diffuse sources ( $\mathrm{cf}$ the acidic-upland and rural catchments).

- The waters are typically calcite oversaturated under baseflow conditions while under highflow conditions they are typically calcite undersaturated.

- For all sites, there is a positive linear relationship between the logarithm of the calcite saturation and the $\mathrm{pH}$, of 
high statistical significance, with no "levelling off" near calcite saturation.

- These final two observations, for the same reasoning provided for the rural rivers, indicate that there are no calcite solubility controls for this type of river system.

\section{The Wear}

This river basin is not as highly industrialized as the other industrial/urban rivers in this group. Consequently, the water quality is like that of the rural Humber rivers that have similar upland characteristics. In particular, the Wear is similar to the Nidd and the Ouse (Ouse2) as all three rivers are influenced by sewage sources, particularly under baseflow conditions. The Wear differs from the other rivers in that while there is a linear relationship between $\log \left(\mathrm{SI}_{\text {Calcite }}\right)$ and $\mathrm{pH}$, the regression relationship is much weaker as reflected by a lower $r^{2}$ value. As for the other rivers, there is no indication of a calcite solubility control. However, the Wear is atypical in that it is in part supplied by pumped mine water that may be in equilibrium with calcite (cf. the discussion below on the Chalk groundwaters - for the Wear, the underlying geology is Carboniferous rocks which are also calcite-rich). Thus, the Wear may represent a mixture of inputs with contrasting calcite saturations that are modified within the river channel by partial degassing carbon dioxide to the atmosphere.

\section{The agricultural catchments}

These catchments comprise the Great Ouse as well as the Thames and its tributaries (the Kennet and the Pang). For all the sites except for one of the Pang sites (Pang2), that is a groundwater-fed spring, the salient features are as follows.

SRP concentrations vary considerably with flow (7 to 102 $\mathrm{mM}-\mathrm{P}^{-1}$ ) for the Great Ouse and the Thames. This represents the impacts of point source effluent discharges that dilute as flow increases superimposed on a background of diffuse inputs directly from agriculture. In contrast, for the Pang and the Kennet, the concentrations are generally lower (1 to $22 \mathrm{mM}-\mathrm{P}^{-1}$ ). For both the Pang and the Kennet, no major declines in SRP concentration with flow were observed except for an earlier phase of monitoring on the Kennet when the lower five monitoring points were impacted by sewage effluent prior to phosphorus removal from the major sewage treatment plant in the area.

DOC concentrations ranged between 225 and 817 $\mathrm{mM}-\mathrm{C}^{-1}$ for the Thames and the Great Ouse and this contrasted with the Pang and the Kennet that had a lower range ( 83 to $570 \mathrm{mM}-\mathrm{C}^{-1}$ ). For most of these rivers, there was a tendency to higher DOC concentrations at higher flows: this reflects a balance between diffuse and point source inputs.
For all the locations on the main river stems and the tributaries, the waters are permanently calcite oversaturated by a factor between two and two hundred-fold. There is no clear relationship between calcite saturation and flow. Rather, there is the same linear relationship between the logarithm of the calcite saturation and $\mathrm{pH}$ to that described above for the other catchment types. Thus, as with the above cases, there is no evidence for calcite solubility controls for these rivers.

\section{Groundwater and groundwater fed springs}

Groundwater and groundwater-fed springs were measured for Chalk areas in the Thames basin in the three Kennet boreholes and the Pang (the Pang2 site), respectively. At all these sites, the waters were approximately saturated with respect to calcite (within a factor of a half to two times saturation). SRP concentrations were relatively low for the Kennet boreholes (less than $0.7 \mathrm{mM}-\mathrm{P} \mathrm{l}^{-1}$ ) and there are no available data for DOC. For the Pang, both SRP and DOC concentrations are relatively low (0.4 to $3.7 \mathrm{mM}-\mathrm{P}^{-1}$ and 67 to $142 \mathrm{mM}-\mathrm{Cl}^{-1}$, respectively). For the Pang2 site, while the SRP levels are low compared to the other rivers monitored, they are higher than for the Kennet boreholes as there are local sewage inputs that have not been "cleaned" within the aquifer (this is shown by the presence of $e$-coli in the water as observed in unpublished reports by the Environment Agency). The DOC for the Kennet boreholes is probably low: the low levels of DOC for the Pang2 site probably represent upper limits for the Kennet boreholes.

There is some relationship between $\mathrm{pH}$ and the logarithm of the calcite saturation although the relationship is particularly weak for the borehole sites. The $\mathrm{pH}$, alkalinity and calcite saturation ranges are all small and it seems that calcite solubility controls may be operating. For the borehole sites, the $\log \left(\mathrm{SI}_{\text {Calcite }}\right)-\mathrm{pH}$ gradient is relatively low as would be expected where calcite solubility controls are active. However, for the Pang spring, a gradient of unity is observed which is similar to that for the nearby streams. This positive gradient probably reflects the influence of carbon dioxide degassing to the atmosphere where the spring emerges and the small $\mathrm{pH}$ change is insufficient to lead to a complete calcite solubility control coming into force. In contrast, the borehole sites represent a closed environment where carbon dioxide degassing would hardly be significant.

\section{Discussion}

GENERAL

The results described above can be summarised as follows. 


\section{The rivers}

For most of the rivers studied, there is the potential for calcite solubility controls particularly under baseflow conditions, but this potential is not realised. Three types of system are observed.

In upland acidic catchment systems, the soils and groundwater zones are generally base depleted.

For this situation, undersaturation arises because both the baseflow and stormflow waters are derived from the groundwater and soil zones that have an insufficient source for major calcium-release/alkalinity-generation. This occurs for one of two reasons. Firstly, there is insufficient calcium in the soil-matrix to break down to enrich the soil/ground waters. Secondly, there is enough calcium in the soil-matrix to dissolve but there is too short a water residence time for sufficient solution to take place.

In the rural and industrial/urban impacted systems, the river waters oscillate between calcite under-and oversaturation.

Oversaturation occurs under baseflow periods when water comes from groundwater sources. For oversaturation to occur, the calcium and carbonate concentrations need to be sufficiently high for the activity product $\left\{\mathrm{Ca}^{2+}\right\} *\left\{\mathrm{CO}_{3}{ }^{2-}\right\}$ to exceed the equilibrium constant for calcite solubility. The groundwaters are enriched in base cations and hence calcium concentrations are relatively high. The groundwaters are also of relatively high alkalinity and the alkalinity is mainly associated with bicarbonate and, to a much smaller degree, carbonate ions. This situation occurs, unlike in the upland situation described above, because groundwater sources are more extensive in the lowland areas, the aquifer sources are often calcium enriched and there will be long residence times for storage and chemical reaction. For these situations, due to the inter-relationships between the reactive species in the inorganic carbon system (dissolved carbon dioxide, bicarbonate, carbonate and hydrogen ions), carbon dioxide degassing raises the $\mathrm{pH}$ sufficiently to increase the carbonate concentrations above that required for calcite supersaturation. The degree of supersaturation increases (for constant calcium and alkalinity levels) with increasing $\mathrm{pH}$ and this occurs when carbon dioxide concentrations are low. Such oversaturation occurs in the situation where carbon dioxide groundwaters degas within the river channel and when photosynthetic activity is particularly high (cf. the Tweed; Neal et al., 1997).

Undersaturation occurs under stormflow conditions when the waters are essentially derived from the soil zones which are insufficient a weathering source for calcium-release/ alkalinity-generation (i.e. calcium levels in the soil-matrix are too low or water residence times are too short). Further, stormflow waters will be influenced by the parts of the basin where the greatest volumetric contribution of flow is derived.
For the lowland rivers, the upland parts of the basin are the high rainfall areas, they contribute the most acidic, and calcite undersaturated waters particularly under high flow conditions.

The variation in calcite saturation changes in relation to flow. The linear change in the logarithm of the calcite saturation with variation in $\mathrm{pH}$ across the flow range reflects mixing processes that do not involve calcite solubility controls. Rather, they reflect a two-component mixing regime of soil and groundwaters of contrasting typology.

In the agricultural catchments, the waters are permanently calcite oversaturated.

For these catchments, the waters are derived from groundwater sources. These groundwater sources have aquifers that are calcite laden and they have sufficient reactivity and sufficient residence time to generate enough calcium and alkalinity for calcite precipitation. The river waters are calcite oversaturated because of three factors. Firstly, the surface waters are overwhelmingly derived from these aquifer sources under both baseflow and stormflow conditions. Secondly, the aquifer matrices are laden with calcite. This matrix is easily/rapidly weathered to produce waters that are calcium and bicarbonate enriched. Thirdly, the groundwaters are overladen with dissolved carbon dioxide (typically about a hundred times atmospheric pressure, Neal et al., 2001) and this degasses in the river to about ten times the atmospheric pressure (Neal et al., 2000c). This feature leads to a $\mathrm{pH}$ rise which increases the carbonate concentration above the threshold for calcite precipitation.

Overall observations on calcite solubility with the rivers.

There is no evidence for a calcite solubility control within the water column of any of the rivers studied. Rather, the saturation index changes in relation to flow and/or biological activity in such a way that the logarithm of the saturation indexes varies in a linear way with $\mathrm{pH}$ across all the rivers. The gradient varies from site to site and it is linked to two features.

1. $\log \left(\mathrm{SI}_{\text {Calcite }}\right)$ is calculated using the $\mathrm{pH}$ and for a situation with no calcite solubility controls, there is an autocorrelation factor of minus one.

2. As flow increases, not only does $\mathrm{pH}$ decline, but so too do the calcium and bicarbonate concentrations due to the increase in the soil water component in some situations. For these cases, $\log \left(\mathrm{SI}_{\text {Calcite }}\right)$ is directly related to the logarithm of the calcium and the bicarbonate concentration and so there is an underlying structure to the data that produces a change in $\log \left(\mathrm{SI}_{\text {Calcite }}\right)$ similar to that for $\mathrm{pH}$.

Thus, there is, broadly, a change in gradient from 2.4 to 1.0 
from the northern acidic sites through the industrial/urban rivers to the agricultural rivers of the south and a progressive decline in the influence of flow related changes in calcite saturation.

\section{The groundwaters and spring fed areas}

For all these sites, the waters are approximately saturated with respect to calcite. In addition, within these regions, the waters are in contact with the mineral calcite and for the emergent spring at the Pang2 site, calcite precipitation is actively observed (Neal et al., 2001). Further, around the Kennet and Pang region, spring waters carrying fine white precipitates (probably calcite) are observed emerging either at surface sites or within slower stretches of the shallower and slower moving parts of the rivers. At these sites, SRP and DOC concentrations are particularly low and it seems that calcite solubility controls are operative and may well be stripping SRP from solution.

Although there will be groundwater contamination by SRP and DOC calcite solubility controls, it might well be expected in these areas because of two factors. Firstly, within aquifer processes lead to SRP/DOC decline thus increasing the potential for calcite nucleation. For example, it is well established that waters in the unsaturated zone are enriched in SRP and DOC from agricultural pollution and that these concentrations decay from solution on passage through the system (Montgomery et al., 1988; Goody et al., 2000). Secondly, the aquifer offers a high potential for calcite precipitation onto active nucleating centres. Thus, the aquifer matrix contains a high surface area of calcite since the volumetric content of calcite is high and the calcite grains are small.

\section{ASSO CIATED RESULTS}

Within this presentation, all the findings indicate that there is no evidence for calcite precipitation within the water column of the rivers studied. Rather, it is the groundwater areas where such controls are operative. So, do calcite precipitation and SRP co-precipitation never occur within the rivers? The answer to this seems to be no, because there is a need to consider the nature of biological processes at the water column interface. Plant-water and sediment-water interfaces within rivers are areas of high biological activity with respect to the carbon dioxide system and this in turn affects the $\mathrm{pH}$ of the solutions near the surfaces and the degree of calcite saturation. The water column can show large fluctuations in the degree of carbon dioxide saturation within a daily time frame, particularly during the summer months when low flows predominate and calcite saturation is at its highest. During this period, photosynthetic activity, particularly within the shallower rivers where macrophyte levels are high, leads to high carbon dioxide loss from the water column and an increase in $\mathrm{pH}$. This change is also marked with algal blooms in the water column. In contrast, biological activity associated with respiration (e.g. bacterial decay processes both during the night and the day as well as by plants during the night) leads to carbon dioxide enrichment within the water column and $\mathrm{pH}$ declines leading to a reduction in the degree of calcite oversaturation. While the changes are marked within the water column, the active sites are at the interface between the plants/sediments and the water column and it is here where the extremes in water chemistry will be observed. Indeed, the kinetics for solubility controls at surfaces are extremely complex and there is a wider range of factors that can inhibit or promote nucleation (Plummer et al., 1979; Appelo and Postma, 1993). Current research within the lowland rivers of the UK reveals two features:

1. SRP loss can occur along river channels where no intermediate sources complicate the issue (House and Denison, 1997; Jarvie et al., 2001).

2. Calcite precipitation can occur with algal development on surfaces (Hartley et al., 1995, 1997; Jarvie et al., 2001).

Thus, it does seem that within-river calcite solubility controls may apply within the lowland rivers at a time of calcite supersaturation, but the rate and extent of the uptake is not sufficiently high to affect the calcite saturation status within the water column.

Taking the stream and groundwater data as a whole, it seems that:

1. The potential for calcite precipitation is highest at baseflow in the rivers. However, at such a time, SRP is typically at its highest and nucleation of calcite would be impeded.

2. Based on the present data, it seems that with the potential for calcite to precipitate, the SRP must be less than $4 \mathrm{mM}$ $\mathrm{Pl}^{-1}$ and DOC must be less than $150 \mathrm{mM}-\mathrm{Cl}^{-1}$ for a calcite solubility control to be effective with a high number of nucleation centres. This provides an upper bound for precipitation within river systems where nucleation centres are much more limited. Laboratory studies indicate that the inhibitory action of SRP and DOC starts at much lower concentrations of less than $1 \mathrm{mM}-\mathrm{P}^{-1}$ and less than 10mM-C $1^{-1}$ (Appelo and Postma, 1993). For river systems, the inhibition probably occurs between these two bounds.

3. Conditions (1) and (2) seem to conspire to ensure that calcite solubility controls are not operating in the wideranging $U K$ rivers studied here. 
With respect to the estuarine and coastal environment, despite extensive hydrochemical research as part of programmes such as the LOIS, they have not provided data in this area because of lack of a complete water quality record. Thus, while $\mathrm{pH}$ and SRP concentrations are widely measured, this is not the case for the other two measures needed to compute calcite saturation, calcium and alkalinity. Within these estuarine and coastal areas, calcium and bicarbonate concentrations are particularly high and clearly, calcium carbonate precipitation can occur. However, the precipitation of calcite and other forms of calcium carbonate may not occur within the water column because of inhibiting factors of SRP, DOC and other species such as magnesium (Berner, 1975; Berner et al., 1978; Mucci, 1986; Appelo and Postma, 1993; Drever, 1997). Within the estuarine and coastal environment, SRP and DOC pollution from the riverine sources can decline due to dilution of river water by sea water and levels may start to go below those needed to inhibit calcite precipitation within the water column. Further, there may be parts of the estuarine and coastal waters where biological activity may produce conditions analogous to those in the river where calcite precipitation becomes optimal. Set against this, sediment-water interactions can maintain anomalously high SRP levels within an estuarine environment (Liss, 1972) and it is not clear where the net relationship between precipitation and dissolution for calcite and SRP lies. It is hoped that the present research will stimulate further research within these areas.

\section{Conclusions and wider comments}

The present study and associated work indicate that calcite solubility controls are not operating within the water column of UK rivers. However, calcite solubility controls may well be operating within calcite-laden aquifers and at the interface between river water and sediment at periods of calcite supersaturation within the water column. Where calcite solubility controls are operative, then there may well also be some regulation of phosphate levels. Groundwaters represent an important surface water resource in many areas and hence, their influence in regulating phosphate levels may well be important. The surface and groundwater data indicate that for calcite solubility controls to be operative, there are upper bounds for SRP and DOC concentrations. These bounds are about $4 \mathrm{mM}-\mathrm{P}^{-1}$ and $50 \mathrm{mM}-\mathrm{Cl}^{-1}$, respectively, in the presence of nucleation centres. Clearly, for river systems, these concentration bounds must be lower owing to the absence of nucleation centres. For estuarine and marine systems, lower bounds are probably required owing to the presence of other nucleation inhibitors. Set against this, biological processing may well be important at the interface between aquatic plant/animal communities and the water column, rather than in the water column itself for both saline and non-saline systems. The importance of the sediment/plant water column interface is not adequately understood. This area of research also deserves further attention.

\section{References}

Appelo, C.A.J. and Postma, D., 1993. Geochemistry, groundwater and pollution. Balkema, Rotterdam, 536pp.

Berner, R.A., 1975. The role of magnesium in the crystal growth of calcite and aragonite from sea water. Geochim. Cosmochim. Acta, 39, 489-504.

Berner, R.A., Westrich, J.T., Graber, R., Smith, J. and Martens, C.S., 1978. Inhibition of aragonite precipitation from supersaturated seawater: a laboratory and field study. Amer. J. Sci., 278, 816-837.

Cresser, M.S., Smart, R., Billett, M.F., Soulsby, C., Neal, C., Wade, A., Langan, S. and Edwards, A.C., 2000. Modelling water chemistry for a major Scottish river from catchment attributes. J. Appl. Ecol., 37, 171-184.

Crossland, C.J., Kremer, H. and Marshall, J.I. (Eds), 1999. Regimes of Coastal Change. 4th Open Science Meeting, LOICZ, Bahia Blanca, Argentina, 15-18 November, 1999. LOICZ International Project Office, Netherlands Institute of Sea Research, (NIOZ), P.O. Box 59, 1790-AB Den Burg, Texel, The Netherlands, 146pp.

Drever, J.I., 1997. The geochemistry of natural waters. Prentice Hall, Upper Saddle River, NJ 07458, USA: 436pp.

Goody, D.C., Withers, P.J.A., McDonald, H.G. and Chilton, P.J., 1998. Behaviour and impact of cow slurry beneath a storage lagoon: II. Chemical composition of chalk pore water after 18 years. Water, Air Soil Pollut., 107, 51-72.

Hartley, A.M., House, W.A., Callow, M.E. and Leadbeater, B.S.C., 1995. The role of a green alga in the precipitation of calcite and co-precipitation of phosphate. Int. Rev. Gesamte Hydrobiol., 80, 385-401.

Hartley, A.M., House, W.A., Leadbeater, B.S.C. and Callow, M.E., 1996. The use of microelectrodes to study the precipitation of calcium phosphate upon algal biofilms. J. Colloid Interface Sci., 183, 498-505.

Hartley, A.M., House, W.A., Leadbeater, B.S.C. and Callow, M.E., 1997. Co-precipitation of phosphate with calcite in the presence of photosynthesising green algae. Water Res., 31, 2261-2268.

House, W.A., 1986. Inhibition of calcite crystal growth by inorganic phosphate. J. Colloid Interface Sci., 119, 505-511.

House, W.A., 1990. The prediction of phosphate coprecipitation with calcite in freshwaters. Water Resour. Res., 24, 1017-1023.

House, W.A. and Denison, H.F., 1997. Nutrient dynamics in a lowland stream impacted by sewage effluent: Great Ouse, England. Sci. Total Envir., 205, 25-49.

Inskeep, W.P. and Bloom, P.R., 1986. Kinetics of calcite precipitation in the presence of water-soluble organic ligands. Soil Sci. Soc. Amer. J., 50, 1167-1172.

Jarvie, H.P., Neal, C. and Robson, A.J., 1997. The geography of the Humber catchment. Sci. Total Envir., 194/195, 87-100.

Jarvie, H.P., Neal, M. and Neal, C., 2001. The role of algal biofilms for phosphorus uptake in a lowland chalk stream, the River Kennet, UK. Sci. Total Envir., in press.

Kleiner, J., 1988. Coprecipitation of phosphate with calcite in lakewater: a laboratory experiment modelling phosphorus removal with calcite in Lake Constance. Water Resour., 22, 12591265.

Langan, S.J., Wade, A.J., Smart, R., Edwards, A.C., Soulsby, C., Billett, M.F., Jarvie, H.P., Cresser, M.S., Owen, R. and Ferrier, 
R.C., 1997. The prediction and management of water quality in a relatively unpolluted major Scottish catchment: current issues and experimental approaches. Sci. Total Envir., 194/195, 419435.

Leeks, G.J.L. and Jarvie, H.P., 1998. Introduction to the Land-Ocean Interaction Study (LOIS): rationale and international context. Sci. Total Envir., 210/211, 5-20.

Liss, P.S., 1976. Conservative and non-conservative behaviour of dissolved constituents during estuarine mixing. In: Estuarine Chemistry (Eds. J.D. Burton and P.S. Liss) Academic Press, London, 93-130.

Mainstone, C.P., Parr, W. and Day, M., 2000. Phosphorus and River Ecology: tackling sewage inputs. English Nature, Northminster House, Peterborough, PE1 1UA, UK, 1-46.

Montgomery, H.A.C., Shaw, P.J. and Cheeseman, R.V., 1988. Water quality changes in a septic tank effluent discharged to the Chalk. J. IWEM, 2, 361-364.

Mucci, A., 1986. Growth kinetics and composition of magnesian calcite overgrowths precipitated from seawater: quantitative influence of orthophosphate ions. Geochim. Cosmochim. Acta, 50, 217-233.

Neal, C., 2001. Calcite saturation in eastern UK rivers. Sci. Total Envir., in press.

Neal, C. and Robson, A.J., 2000. A summary of river water quality data collected within the Land Ocean Interaction Study: core data for Eastern UK rivers draining to the North Sea. Sci. Total Envir., 251/252, 587-668.

Neal, C., Robson, A.J., Harrow, M., Hill, L., Wickham, H., Bhardwaj, C.L., Tindall, C.I., Ryland, G.P., Leach, D.V., Johnson, R.C., Bronsdon, R.K. and Cranston, M., 1997. Major, minor, trace element and suspended sediment variations in the River Tweed: results from the LOIS core monitoring programme. Sci. Total Envir., 194/195, 193-206.

Neal, C., House, W.A. and Down, K., 1998. An assessment of excess carbon dioxide partial pressures in natural waters based on $\mathrm{pH}$ and alkalinity measurements. Sci. Total Envir., 210/211, 187204

Neal, C., Jarvie, H.P., Whitton, B.W. and Gemmell, J., 2000a. The water quality of the River Wear. Sci. Total Envir., 251/252, 155174.

Neal, C., Jarvie, H.P., Williams, R.J., Pinder, L.C.V., Collett, G.D., Neal, M. and Bhardwaj, L., 2000b. The water quality of the Great Ouse. Sci. Total Envir., 251/252, 423-440.

Neal, C., Williams, R.J., Neal, M., Bhardwaj, L.C., Wickham, H., Harrow, M. and Hill, L.K., 2000c. The water quality of the River Thames at a rural site downstream of Oxford. Sci. Total Envir., 251/252, 441-458.

Neal, C., Neal, M., Wickham, H. and Harrow, M., 2000d. The water quality of a tributary of the Thames, the Pang, southern England.
Sci. Total Envir., 251/252, 459-476.

Neal, C., Jarvie, H.P., Howarth, S.M., Whitehead, P.G., Williams, R.J., Neal, M., Harrow, M. and Wickham, H., 2000e. The water quality of the River Kennet: initial observations on a lowland chalk stream impacted by sewage inputs and phosphorus remediation. Sci. Total Envir., 251/252, 477-496.

Neal, C., House, W.A., Leeks, G.J.L., Whitton, B.A. and Williams, R.J., 2000f. Conclusions to the special issue of Science of the Total Environment concerning "The water quality of UK rivers entering the North Sea". Sci. Total. Envir., 251/252, 557-573.

Neal, C., Williams, R.J., Jarvie, H.P., Neal, M., Wickham, H. and Hill, L., 2001. Phosphorus - calcium carbonate solubility relationships in a lowland chalk stream impacted by sewage inputs and phosphorus remediation: an assessment of phosphorus selfcleansing mechanisms in natural waters. Sci. Total Envir., in press.

Perry, J. and Vanderklein, E., 1993. Water quality: management of a natural resource. Blackwell Science Inc, Cambridge, Mass., 639pp.

Plummer, L.N., Parkhurst, D.L. and Wigley, T.M. L., 1979. Critical review of the kinetics of calcite dissolution and precipitation. In: Chemical modelling in aqueous systems (Ed. E.A. Jenne). American Chemical Society Symposium Series, Washington D.C., 93, 537-573.

Robson, A.J. and Neal, C., 1997. Regional water quality of the River Tweed. Sci. Total Envir., 194/195, 1173-192.

Rossnecht, H., 1980. Phosphatelimitation durch Autochtone Calcitfallung im Bodensee-Obersee. Arch. Hydro., 88, 328-344.

Smart, R.P., Soulsby, C., Neal, C., Wade, A., Cresser, M.S., Billett, M.F., Langan, S.J., Edwards, A.C., Jarvie, H.P. and Owen, R., 1998. Factors regulating the spatial and temporal distribution of solute concentrations in a major river system in NE Scotland. Sci. Total Envir., 221, 93-110.

Smith, D.I., 1999. Policy, serendipity and science: algal blooms in Australia. In: Water Quality, Processes and Policy (Eds. S.T. Trudgill, D.E. Walling and B. Webb), Wiley, Chichester, UK, $135-150$.

Stumm, W. and Morgan, J.J., 1996. Aquatic Chemistry ( $3^{\text {rd }}$ edition). Wiley, New York, USA, 1022pp.

Suarez, D.L. and Rhoades, J.D., 1982. The apparent solubility of calcium carbonate in soils. Soil Sci. Soc. Amer. J., 46, 716-722.

Thomson, M.B., 1983. Effect of precipitation inhibitors on calcium carbonate scale formation. J. Cryst. Growth, 62, 106-112.

Wade, A.J., Neal, C., Smart, R.P. and Edwards, A.C., 2001. Calcite saturation in the River Dee, NE Scotland. Sci. Total Envir., in press.

Walter, L.M. and Hanor, J.S., 1979. Effect of orthophosphate on the kinetics of biogenic magnesian calcites. Geochim. Cosmochim. Acta, 43, 1377-1385. 